\title{
Interfaith Dialogue: Countering Radicalism by The Innovation of Model Religious Education
}

\author{
$1^{\text {st }}$ Isnawati $^{1}, 2^{\text {nd }}$ Arif Zamhari ${ }^{1}, 3^{\text {rd }}$ Muhammad Yusuf $^{1}, 4^{\text {th }}$ Dewi Aprilia Ningrum ${ }^{1}, 5^{\text {th }}$ Dede \\ Rosyada $^{1}$ \\ \{isnawati17@mhsuinjkt.ac.id ${ }^{1}$, arif.zamhari@uinjkt.ac.id ${ }^{1}$, muhammad_yusuf17@mhs.uinjkt.ac.id ${ }^{1}$ \}
}

UIN Syarif Hidayatullah, Islamic Studies Departement, Jakarta, Indonesia ${ }^{1}$

\begin{abstract}
This article arguess interfaith dialogue can be used to prevent the development of radicalism by including this model to the education system in Indonesia where students can dialogue directly with students of different religions to gain more understanding and comprehensive knowledge about other religions and foster a sense of tolerance and the importance of respecting differences. But this model should be accompanied by a change in the direction of the religious education system from exclusive to inclusive, because the understanding of an exclusive religion will be a trigger for the development of radicalism. Understanding exclusivism makes the lack of understanding students of other religions.
\end{abstract}

Keywords: Interfaith Dialogue, Radicalism, Innovation of Model Religious Education

\section{Introduction}

Indonesia as a nation with Unity in Diversity is well known for its assorted variety. One of them is pluralism in religion, where there are 6 officially recognized religions in Indonesia namely Islam, Protestant Christianity, Catholicism, Hinduism, Buddhism and Confucianism. Form that reality, cannot deny the existence of differences both in terms of understanding, habits and traditions so as to allow for conflict between religious communities. Basically all religions teach peace and avoid conflict, yet narrow mindedness among adherents of religion still occurs due to lack of understanding of other people's religions [21].

Recently, one of the enermous challenges facing the Indonesian people is the infiltration of radicalism which is currently focused on the younger generation [43]. The plurality of religions without being based on a decent understanding among religions can be utilized by radical terrorist groups who want to separte the unity and integrity, especially in terms of ideology. Seeing this big challenge, it is necessary for having synergy to strengthen and maintain the integrity of the Republic of Indonesia [50].

One source of the growth and development of radical terrorism understandings stems from a wrong understanding or distortion of religious teachings. This is dangerous because can disturb harmony and peace also causes fear. Radicalism causes terror in the name of religion must be counteracted through anticipation and complete discouragement with the aim it is not increasingly developed in society [5]. Harmony in religious life becomes a strength 
also efforts to prevent the development of this understanding and at the same time become capital in entering this progressively perplexing worldwide life.

Knitter emphasized that interfaith dialogue as one way to promote respect for differences that can encourage cooperation and prevent conflicts between religious [25][42]. Furthermore Urbano also included that one of the triggers of pressure between religious communities was the lack of interaction each other. According to Urbano, association between religious communities can lead to a conscious process in understanding the importance and beliefs of other religions when completed in harmony (R. Urbano: 2012).

The above is in accordance with what was carried out by the National Counterterrorism Agency (BNPT) as a representative of the government carrying out interfaith dialogue activities in the Prevention of Radical Terrorism Understanding in Solo, Central Java, on Wednesday 24 July 2017 [26] as one of the preventive endeavors to counter radicalism. This action is an effort to develop strategic relationships with religious and community leaders through synergy with the Ministry of Religion in order to prevent the spread of radicalism and terrorism. The action aims to garner the spirit of religious and community leaders to equalize perceptions related to the prevention of the understanding of radical terrorism, as well as to provide understanding and knowledge about the understanding of radical terrorism. Besides that, it is to build the deterrent power of the community, particularly to religious leaders and community leaders through dialogue against radical terrorism.

The occurrence of various conflicts in the name of religion has become one of the triggers for the clash of relations between religious communities today. beginning from fundamentalism, radicalism to terrorism which lately increasingly frequent in the country. Religious nuances are indicators that show real signs of national disunity. In Indonesia there are several events that occurred 4 years straight that are closely related to radicalism, bombings in several places such as Legian Bali on October 12, 2002, JW Marriot Hotel Jakarta on August 5, 2003, Australian Embassy Jakarta on September 9, 2004, Tentana on May 28, 2005 and Pamulang on June 8, 2005 [15] [45]. Not only in Indonesia but also in other parts of the world such as the Marawi conflict in the Philippines and the Rohingya case in Myanmar that occurred in 2017 (Humphrey Wangke: 2017, Ribut Lupiyanto: 2015). ??????

Another more astonishing fact is a result of research conducted by PPIM UIN Jakarta which states that the potential for radicalism and intolerance has entered the religious education system in Indonesia. This statement is supported by the facts on the ground, religious teachers who are supposed to be guides as well as supervisors in developing tolerance, inclusive and pluralist attitudes towards students show the opposite, this phenomenon is getting worse with the spread of Islamic Religious Education textbooks (PAI) taught in public schools that teach about radicalism and intolerance [39].

The facts above make us aware that our nation is facing a big problem. Even lately there has been a commotion in the public sphere with the emergence of voluminous Islamic defenses, expressions of hatred and the phenomenon of the emergence of neo-conservative groups [49] as well as suicide bombings which are more or less an accumulation of errors in the existing education system. in Indonesia especially religious education [42]. Seeing the reality, religious education which emphasizes the importance of dialogue is one of the main needs at this time. This educational model is one of harmonization efforts in relations between religious communities [6].

The realities above is big sign that our nation is facing a big problem. Indeed, even lately there has been a commotion in the public sphere with the emergence of voluminous Islamic defenses, expressions of hatred and the phenomenon of the emergence of neo-conservative groups [49] as well as suicide bombings which are more or less an accumulation of errors in 
the existing education system. in Indonesia especially religious education [42]. Seeing the reality, religious education which emphasizes the importance of dialogue is one of the main needs at this time. This educational model is one of harmonization efforts in relations between religious communities [6][54].

Based on this issue, we feel necessary to conduct a further research for countering radicalism in Indonesia through the innovation of religious education by interfaith dialogue.

\section{Literature Review}

There are several studies that have been conducted regarding interfaith dialogue also the prevention of radicalism. Among others are:

First, a dissertation entitled "Developments in Religious Studies: Towards a Dialogue with Religious Education" which explains interfaith dialogue in education which was subsequently popularized by universities in the UK. It was further explained that the concept of interfaith dialogue in religious learning in schools can trigger the creation of better and more open religious learning [12].

Second, a book called "The Multifaith Movement: Global Risks and Cosmopolitan Solutions" which describes the benefits as well as challenges that will be faced by the interfaith dialogue movement. In this paper it is explained that there are 3 principles and goals that can be achieved through interfaith dialogue, namely developing an understanding of religious differences and the reality of belief that is not single, normalizing exclusivity by inculcating the concept of pluralism ideology and creating a network of peace in facing the global world [16].

Third, a dissertation entitled "interfaith religious education" which describes the implementation of the interfaith religious education model in 3 institutions in Indonesia. This study reveals that the application of the concept of religious pluralism in religious education materials is needed with the aim of students not only understanding their religion but also having knowledge of other religions [42].

\section{Methodology}

This research is a qualitative research using library research methods, which is conducted by reading books, reports, journals and topics related to this research. [11], [33], [48], [38], M. Syahran Jailani: 2013, [32].

\section{Result and Finding}

\subsection{The Concept of Interfaith Dialogue}

In the particular term dialogue has many meanings and uses, depending on the context and perspective. According to Leonard Swidler dialogue is a conversation between two or more people with different views, with the main goal that everyone can learn from others so they can change and grow [47]. In the Islamic perspective, dialogue is the best way to gain a 
complete understanding of Islam. Ismail Raji al-Faruqi defines dialogue as a da'wah and mission in the dimension of human consciousness based on noble humanitarian ethics [4]. This concept of dialogue is part of an effort to bring together two different sides.

Actually, interfaith dialogue begins by Christian circles. This dialogue was held at that time with the aim that Christian missionaries could be welcomed in the countries where they carried out respectful activities. Through this interfaith dialogue also for showing show to non-Christians that Christian missionaries can carry out their activities in the midst of other religious communities without damaging one's faith [41].

At the time, interfaith dialogue was welcomed by Muslims who were educated in the Western world, including Tariq Ramadan, Jamal Badawi, Mohammed Abu-Nimer and those who were educated in traditional institutions in the Islamic world such as Abdurrahman Wahid, Fethulleh Gullen and Yusuf al-Qardhawi also who have Western and Islamic educational backgrounds as well as Ismail Ragi al-Faruqi. At the same time, since the 1990s many studies have begun to discuss the role of Islam in interfaith dialogue and building world peace has increased [2].

According to Abu-Nimer, interfaith dialogue is one of alternative and substitute ways of debating religious interaction which has a negative impact.. Dialogue is intended to create tolerance and respect for other religions, even serves to understand all the existing religious complexities, while the debate model is considered have the potential for rejecting others from different beliefs [3].

There are several things that make interfaith dialogue suspected and misunderstood. Interfaith dialogue is considered to be able to cause religious conversion and efforts of mixturing religious beliefs. Yet according to Abu-Nimer the main purpose of this dialogue is helping communities to understand and respect each other. Someone who has no dialogue experience at all will be hesitant and difficult to build a perspective of living together. On the contrary, interfaith dialogue can be a place to find out their own faith and to know other religious beliefs. Therefore, conversion of religion is not the main goal in interfaith dialogue, when a person enters the dialogue space must be balanced with a strong personal understanding of his religious beliefs [41].

\subsection{Exclusivism vs Inclusivism in Religious Education}

In the context of globalization we do not avoid the existence of very rapid changes. These affect all aspects of life including education. Education should be a process of institutionalizing morality and ethics to students [30] [42]. The world of education including religious education is one of the dominant factors in impacting the development of students' mindset. But in reality, the education world is currently considered less able to respond to the problems currently faced by the younger generation [36], [10], [23].

Religious values giving positive impact when students are able to discourse and come into direct contact with the existing reality. Religious education in terms of material and methodology of slowing development when compared with developments outside the school [1]. The material taught at school also has not been able to be absorbed and respond to current problems. Curriculum reform is hard because it is hampered by the complicated centralization and education bureaucracy. Moreover education practitioners are actually trapped and 
shackled by syllabi and routine activities that are included in teaching and learning activities [34].

Islamic religious education is currently facing a central issue that is human associations with others that not good enough also lacking of appreciation of moral teachings [7]. One of the factors that influence is terrible beliefs. Therefore, constructive and innovative efforts are needed which are simultaneous and continuous.

Numerous actions aimed for the practice of implementing religious education in educational institutions today are seen as more emphasis on cognitive aspects [44] [37]that standars out other dimensions namely affective and conative-volutive (behavior and will). It can be seen from all aspects of the education process which includes curriculum formulation, content and material, learning methods and evaluation which all emphasize more on the cognitive aspects.

Today, the reality of religious education in schools is apparently doctrinal, monologue and filled with formalities which tend to reject the plural reality in religion [29]. In addition, the evaluation phase likewise tends to be biased. This custom is seen from the benchmarks utiized in assessing students, whether in the mastering of material as a doctrine or furthermore on the transgression which is a manifestation of one's religious faith [36]. This is the reality of religious education practices in schools today that are expected to be able to answer the problems that exist today. This expectation, according to the writer, would be impossible if it was not accompanied by innovations in teaching religious education in schools that were able to change the direction and style of religious instruction.

The reason for religious exclusivism in the religious education dimension is the attitude of students who consider certain religions to have genuine truth [53]. According to the author as a Muslim believes that only Islam is the true religion yet must be accompanied by an awareness that we have an commitment to tolerate, respect the beliefs, opinions and thoughts of others who differ from us. It can be achieved when students are equipped with knowledge about other religions as one of the methods of inculcating an inclusive and tolerant attitude that can counteract the development of radicalism in students. This is in accordance with what was conveyed by Ulil Absar Abdalla who stated that all religions are true according to their respective adherents (Ulil Absar Abdalla: 2002). ?????

The attitude of exclusivism will bring forth to the view of teachings which assumes that only the religion that is embraced is the true religion, while other religions are heretical and must be eroded or their followers converted, because religion and its adherents are condemned in God's view [20]. This attitude is a dominant view from time to time, and continues to be adhered to today [9]. Problems will arise along with the assumption that his religion is the most correct. From this there will arise a demeaning attitude towards other religions that can result in judgment of other religions and even accuse other religions as infidels and heretics.

In the terminology of religious pluralism there is also the term inclusive theology. This theology considers that there is truth in other religions, although at the same time they are embracing their religion (George B. Grose \& Banjamin J. Hubbard: 1999) ?????. Komaruddin Hidayat also included the same thing that outside of the religion he embraced there was also truth, although it was not as complete or as perfect as his religion. Here we still find theological tolerance and faith [20], as well as the Nurcholish Madjid which states that this inclusive attitude views other religions as an implicit form of our religion [28]. 
This inclusive attitude should be a reference in the development of religious education in schools. So that the next generation of the nation will be born who appreciate the diversity of inclusive and tolerant character that has been formed in the school environment. The ability to be able to see differences and diversity tolerantly does not come and grow alone but must be instilled and developed through religious education that upholds the principles of pluralism and multiculturalism [28].

The inculcation of the value of religious pluralism in religious education is an important part of efforts to reinforce an attitude of respect for the identities and beliefs of other religions. This is considered important because the existing formal educational institutions seem to teach religious education in the spirit of missionaries and da'wah [14]. Therefore, it is essential to reorient religious education that puts forward the spirit of respect for other religions.

Seeing this reality, the existence of innovation in the model of religious learning in schools should be done. Innovation and changes in the direction of religious education can also be one way to prevent the growth of radicalism as well as an effort of conflict resulition (Deborah L. Javine: 2006).????? Furthermore, the concept of balanced and high-quality learning in religious education learning is needed to support the innovation of this learning model to avoid the introduction of an exclusively-dogmatic understanding of religion [51]. So that in the process of understanding religious doctrine is not trapped in the imposition of belief in students which can lead to the assumption that only his own religion is true.

\section{3 Interfaith Dialogue in The Religious Education.}

The aim of dialogue is to raise the awarness of unity in diversity. in differences. Diversity should not be a barrier to meeting in a dialogic atmosphere. Efforts to develop a comprehensive dialogue and touch the basis of religion for every person can be started from the practice of dialogue between students in the academic environment in the educational institutions [42]

According to the writer, religious education as is the part of the existing education curriculum in the national education system in Indonesia should be direct for growing respect in diversity in accordance with the principles of religious pluralism. Religious education also be used as an effort to develop tolerance and recognition of the importance of religious freedom which is the main point in interfaith dialogue in the dimensions of religious education.

There are several benefits from interfaith dialogue that conducted by students who represent their religions. First, interfaith dialogue be an important step in finding the values of civilization in each side of the truth of a religion. Second, foster understanding in cultural differences and religious beliefs. Third, minimize the occurrence of violence that leads to conflicts between religions. Fourth, as a way to counteract the understanding of radicalism because through this dialogue students will get enough knowledge and understanding of other religions so that they can become strongholds to remain aware of the importance of respecting other religions.

Schools should be a media for interfaith dialogue to foster respect for studentwho come from different faiths. Learning systems in schools should be able to provide dialogical space for students to celebrate differences in beliefs in a harmonious and full of familiarity. During this religious education taught in schools is limited to knowing the difference that Islam is 
different from other religions without a systematic explanation of why and how such differences exist.

According to the author, this is one of the differences between religious differences in Indonesia. Students do not have comprehensive knowledge of other religions than their religions, so that sometimes it causes allegations and wrong judgments of other religions. Basically tolerance and respect for differences should be taught since students entering formal education institutions to create a peaceful life without conflict and riots (Arifah Suryaningsih et al: 2016). Students who understand the difference will be easier to understand and realize the importance of respect the other student from different religions.

The religious learning system in schools especially Islamic religious education should be able to develop plural and humanist religious education as well as related and relevant subjects with respect for differences (Indriyani Ma'rifah: 2016). This religious learning system make students understand more in facing the turmoil of differences in belief in the community later.

\section{Conclusions}

Interfaith dialogue which tends to be conducted only by elites and religious leaders must begin to be taught to students in the school environment. Students as the next generation must be taught to be involved in dialogue directly with other students of different religions. Begin with an innovative model of religious learning that previously focused on the doctrine to interfaith dialogue that students have comprehensive knowledge of other religions with a balanced understanding and strong faith in their own religion. So they have a high sense of tolerance which will have an effect on the lack of radicalism in their later development. The religious education system must also have changed from exclusive to inclusive, because inclusive religious learning can trigger the development of radicalism in students.

Acknowledgements. This research supported by The Graduate School of Islamic Studies UIN Syarif Hidayatullah.

\section{References}

[1] Abdullah, Amin. Dalam Elga Srapung \& Tri Widianto (ed), Pluralisme, Konflik dan Pendidikan Agama di Indonesia. Yogyakarta : Dian Interfedei. 2005.

[2] Abu-Nimer, Mohammed. Dialogue, Conflict Resolution, and Change: Arab-Jewish Encounters in Israel. Suny Press, 1999.

[3] Abu-Nimer, Mohammed, Amal Khoury, and Emily Welty. Unity in diversity: Interfaith dialogue in the Middle East. US Institute of Peace Press, 2007.

[4] Al-Faruqi, Ismail Raji. Islam and other faiths. IIIT, 1998.

[5] Ali Muhtarom, M. H., et al. Islam Agama Cinta Damai: Upaya Menepis Radikalisme Beragama. CV. Pilar Nusantara, 2019.

[6] Arif, Muhammad. "Pendidikan Agama yang Inklusif-Multikultural dalam Bingkai Keislaman dan Keindonesia-an" Jurnal Al-Fikr Volume 15, Nomor 2. 2011.

[7] Azizi, A. Qodri. Pendidikan (Agama) untuk Membangun Etika Sosial. Semarang : aneka Ilmu. 2002.

[8] Azra, Azyumardi. Dari Harvard Hingga Makkah. Jakarta : Penerbit Republika. 2005.

[9] Budi M. Rachman, Islam Pluralis Wacana Kesetaraan Kaum Beriman. Jakarta : Paramadina. 
2001

[10] Cahyono, Heri dan Arief Rifkiawan Hamzah. "Upaya Lembaga Pendidikan Islam Dalam Menangkal Radikalisme." At-Tajdid: Jurnal Pendidikan dan Pemikiran Islam 2.01 (2019).

[11] Creswell, John W. "Research design: pendekatan metode kualitatif, kuantitatif, dan campuran." Yogyakarta: Pustaka Pelajar. 2016.

[12] Cush, Denise, and Catherine Robinson. "Developments in religious studies: towards a dialogue with religious education." British Journal of Religious Education 36.1 (2014): 4-17.

[13] Farikhatin, Anis, et al. "Mengelola Keragaman di Sekolah." 2016.

[14] Francis, Leslie J., William K. Kay, and William S. Campbell, eds. Research in religious education. Gracewing Publishing, 1996.

[15] Fuaduddin, T. M. "Pondok Pesantren Islam Al-Mukmin Ngruki: Studi Tentang Faham Keagamaan Salafi." EDUKASI: Jurnal Penelitian Pendidikan Agama dan Keagamaan 3.2 (2017)

[16] Hallafoff, Anna. "Social Movements, Cosmopolitan and Multifaith Engagement" The Multifaith Movement : Global Risks and Cosmopolitan Solutions. Springer, Netherlands. 2013.

[17] Hallafoff, Anna. "Benefits and Challenges of Multifaith Engagement" The Multifaith Movement : Global Risks and Cosmopolitan Solutions. Springer, Netherlands. 2013.

[18] Hallafoff, Anna. "Multiculturalism, Multifaith Initiatives and Countering Violent Extremisn in Victoria" The Multifaith Movement : Global Risks and Cosmopolitan Solutions. Springer, Netherlands. 2013.

[19] Shafiq, Muhammad, and Mohammed Abu-Nimer. Interfaith dialogue: A guide for Muslims. International Institute of Islamic Thought (IIIT), 2007.

[20] Hidayat, Komaruddin. "Ragam Beragama" Dalam Andito (Editor), Atas Nama Agama, Pustaka Hidayah. 1998.

[21] Irfan, Muh. "Mengkaji Agama-Agama Melalui Pendekatan Interrelegius dalam Meningkatkan Toleransi" Seminar Nasional PKn UNNES. Vol. 3. No. 1. 2019

[22] Jailani, M. Syahran. "Ragam Penelitian Qualitative (Ethnografi, Fenomenologi, Grounded Theory, dan Studi Kasus)." Edu-Bio 4 (2013).

[23] Kamil, Sitti Utami Rezkiawaty, et al. "The Implementation of Information and Communication Technology on Learning Process in Communication Department of UHO Facing Industrial Revolution 4.0 Penerapan Teknologi Komunikasi dan Informasi Pada Pembelajaran Jurusan Ilmu Komunikasi UHO Menghadapi Revolusi Industri 4.0]." Proceeding of Community Development 2 (2019): 344-352

[25] Knitter, Paul F. No other name?: A critical survey of Christian attitudes toward the world religions. Vol. 7. Orbis Books, 1985.R. Urbano : 2012

[26] Labib Zamani pada https://solo.tribunnews.com/2017/05/24/kasubdit-kontra-propaganda-bnptdialog-lintas-agama-sesuai-arahan-jokowi, diakses pada 02 Agustus 2019

[27] Levine, Deborah J. "A Religious Diversity Tale: A Multi-Faith Case Study." American journal of community psychology 37.3-4 .2006.: 203-210.

[28] Madjid Nurcholish. dalam Pengantar George B. Grose. ; Jubbard, Banjamin, J. Tiga Agama Satu Tuhan. Bandung: Mizan. 1999.

[29] Mahmudin, Afif Syaiful. "Pendidikan Islam Dan Kesadaran Pluralisme." Journal Ta'limuna 7.1. 2019.

[30] Mawardi, Imam. "Kurikulum Pendidikan Islam dan Tantangan Dinamika Peradaban Global (Sebuah Pendekatan Paradigmatik)." At-Tajdid: Jurnal Ilmu Tarbiyah 6.1 (2018): 70-90.George B. Grose. ; Jubbard, [31] Banjamin, J. Tiga Agama Satu Tuhan. Bandung: Mizan. 1999.

[32] Merriam, Sharan B. Qualitative Research A Guide to Design and Implementation. United State Of America : Jossey Bass. 2009.

[33] Moleong, Lexy J. Metodologi penelitian kualitatif (Revisi). Bandung: PT Remaja Rosdakarya. 2017

[34] Muhaimin, Paradigma Pendidikan Islam : Upaya Mengeefektifkan Pendidikan Agama di Sekolah, Bnadung : Remaja Rosda Karya. 2001.

[35] Nata, Abuddin. Manajemen Pendidikan: Mengatasi Kelemahan Pendidikan Islam di Indonesia. Kencana, 2012. 
[36] Nata, Abuddin. Pembaruan pendidikan Islam di indonesia. Prenada Media, 2019.Batubara,

[37] Chuzaimah. Handbook Metodologi Studi Islam. Prenada Media, 2018.

[38] Newman, William Lawrence. Social research methods: Qualitative and quantitative approaches. Allyn and Bacon, 1991.

[39] PPIM UIN Jakarta. "Executive Summary, Diseminasi Paham Eksklusif dalam Pendidikan Islam”. Jakarta : September 2016.

[40] PPIM UIN Jakarta. "Policy Brief : Tanggung Jawab Negara terhadap Agama". Jakarta : September 2016.

[41] Said, Abdul Aziz, Mohammed Abu-Nimer, and Meena Sharify-Funk, eds. Contemporary Islam: dynamic, not static. Routledge, 2006.

[42] Salim, Arhanuddin, Pendidikan Agama Lintas Iman. Ciputat : Cinta Buku Media, 2017.

[43] Santalia, Indo, and Syamsul Arif Galib. "Prodi Studi Agama-Agama Sebagai Pelopor Inklusifitas Beragama: Refleksi Pengalaman Prodi Studi Agama-Agama UIN Alauddin Makassar." Religi Jurnal Studi Agama-Agama 15.1 (2019): 1-15.

[44] Sutrisno. Pembaharuan dan Pengembangan Pendidikan Islam. Yogyakarta : Fadilatama. 2011.

[45] Suseno Franz Magnis. "Pluralisme Keberagaman : Sebuah Tanggung Jawab Bersama" dalam Muhammad

[46] Wahyuni Nafis (Editor), Konstekstualisasi Ajaran Islam. Jakarta : Paramadina. 2006

[47] Swidler, Leonard. "The dialogue decalogue: Ground rules for interreligious dialogue." Horizons 10.2 1983.: 348-351.

[48] Ulfatin, Nurul. Metode penelitian kualitatif di bidang pendidikan: Teori dan Aplikasinya. Malang: Bayumedia Publishing, 2015.

[49] Van Bruinessen, Martin, ed. Contemporary Developments in Indonesian Islam: Explaining the" conservative Turn". Institute of Southeast Asian Studies, 2013.

[50] Wibisono, Gunawan. "Membendung Paham Radikalisme Agama dan Ekstrim Kiri dalam Mempertahankan Eksistensi Pancasila." Jurnal Communitarian (Prodi Ilmu Politik) 1.1 (2018).

[51] Wimberley, James. "Education for intercultural and interfaith dialogue: A new initiative by the Council of Europe." Prospects 33.2 (2003): 199-209.

[52] Zainiyati, Husniyatus Salamah. "Pendidikan Multikultural : Upaya Keberagaman Inklusif di Sekolah". Jurnal Islamica. Vol. 1. No. 2. Maret 2015.

[53] Zuhri, Syaifuddin. "Preventing Violent Extremism Dalam Pendidikan Anak Dan Seni." Jurnal Dinamika Penelitian: Media Komunikasi Penelitian Sosial Keagamaan 19.1. 2019.

[54] K. Zada, Fathudin, D. Khairani, and Y. Durachman, "Reduce Extremism through Digital Literacy," 2020. 